\title{
TANTANGAN BERAT REGENERASI PETANI BALI DALAM MEMPERTAHANKAN SUBAK SEBAGAI WARISAN BUDAYA DUNIA
}

\author{
I Made Mahadi Dwipradnyana \\ Dosen Jurusan Ekonomi Pembangunan, Fakultas Ekonomi, Universitas Tabanan \\ Jl. Wagimin No. 8, Kediri, Tabanan - Bali \\ Email: mahady25.md@gmail.com
}

\begin{abstract}
Heavy Challenge of Bali Farmers Regeneration in Supporting Subak as Worldwide Cultural World. The problem facing Indonesian agriculture is the regeneration of farmers. Regeneration is important because based on data from the Badan Pusat Statistik (BPS) the number of farming business households experienced a drastic decrease that originally in the 2003 agricultural census amounted to 492,394 households in 2013 decreased to 408,233 households or decreased by 84,161 household. This will be a serious problem in maintaining the subak system that became world heritage because without regeneration of farmers by themselves the subak system will die. The regeneration of farmers has become a serious concern, the regeneration problem of this farmer looks mediocre, does not look important, does not have drastic impact, but one day will bring harmful effects in the community, especially for the sustainability of Subak in Bali.

The challenge faced by regenerating farmers is that the agricultural sector is less competitive with the tourism sector, the risk of high failure in agriculture, the younger generation considers other sectors more economically and government favoring factors that are considered faster spur economic growth.

Suggestions that can be given is the role of government should be enhanced by integrating tourism with agriculture so that there is a mutually beneficial relationship, multiply training and technology development and provide agribusiness terminals to facilitate farmers to market their agricultural products there is certainty for farmers where selling and the existence of price certainty.
\end{abstract}

Keyword : Bali farmers, farmers regeneration, subak system

\section{PENDAHULUAN}

Tahun 2012 merupakan sejarah bagi pertanian Bali setelah UNESCO menetapkan Subak sebagai Warisan Budaya Dunia dengan label Cultural Landscape of Bali Province: the Subak System as a Manifestation of the Tri
Hita Karana Philosophy (Lanskap budaya Bali: Sistem Subak sebagai Manifestasi Filosofi Tri Hita Karana). Penetapan subak sebagai Warisan Budaya Dunia (WBD) menjadi kebanggaan masyarakat Bali khususnya, dan masyarakat Indonesia pada 
umumnya (Windia dan Wiguna, 2013:205).

Menurut Windia (2006), Subak merupakan organisasi pengairan tradisional dalam bidang pertanian, yang berdasarkan atas seni dan budaya yang diwarisi secara turun temurun oleh masyarakat Bali. Subak adalah organisasi kemasyarakatan yang khusus mengatur sistem pengairan sawah yang digunakan dalam cocok tanam padi di Bali. Subak merupakan sistem irigasi yang berbasis petani (farmer-based irrigation system) dan lembaga yang mandiri (self governmet irrigation institution). Keberadaan subak yang diperkirakan sejak abad ke-11 sampai sekarang ini mengisyaratkan bahwa subak merupakan sebuah lembaga irigasi tardisional yang tangguh dan lestari (sustainable), walaupun eksistensinya kini mulai terancamakibat adanya perubahan-perubahan dalam berbagai segi kehidupan masyarakat Bali terutama pembangunan pariwisata Bali.

Pembangunan pariwisata Bali tidak dapat dipungkiri masuk ke tahap yang mengkhawatirkan atau dengan kata lain pembangunan pariwisata Bali sudah membabi buta. Berdasarkan data yang diperoleh dari Dinas Pertanian dan Hortikultura Provinsi Bali (2016) setiap tahun jumlah lahan pertanian yang mengalami konversi semakin banyak. Inilah tantangan terbesar bagi petanipetani Bali karena disamping berkewajiban untuk bertani sebagai mata pencaharian juga memiliki kewajiban untuk melestarikan sistem subak di tengah tingginya alih fungsi lahan pertanian ke non pertanian.
Permasalahan ini tidak hanya terjadi di Bali Selatan yang menjadi pusat pariwisata, namun jugasudah terjadi di Kabupaten Tabanan yang merupakan pusat pertanian di Bali dan dikenal dengan lumbung berasnya Bali tidak luput dari permasalahan alih fungsi lahan.

Subak Jatiluwih yang menjadi icon pertanian dan pariwisata Tabanan apalagi dengan statusnya sebagai Warisan Budaya Dunia (WBD) menjadi daya tarik bagi pelaku pariwisata untuk melakukan pembangunan di sekitar daerah Jatiluwih. Dapat dilihat saat ini sangat banyak menjamur penginapanpenginapan dan restoran-restoran di sekitar Jatiluwih dan terlihat sangat banyak papan-papan pengumuman "for sale" terpasang di lahan yang merupakan lahan pertanian.

Selain produktivitas dan keterbatasan lahan, masalah lain yang dihadapi pertanian Indonesia adalah regenerasi petani.Pembahasan tentang alih fungsi lahan memang telah menjadi pembahasan hangat mulai dari akademisi hingga politisi, namun dalam penelitian ini permasalahan yang coba diangkat yang tidak kalah pentingnya adalah regenerasi petani. Regenerasi menjadi penting karena berdasarkan data dari Badan Pusat Statistik (BPS) Provinsi Bali jumlah rumah tangga usaha pertanian mengalami penurunan yang cukup drastis yang semula pada sensus pertanian tahun 2003 berjumlah 492.394 rumah tangga pada tahun 2013 mengalami penurunan menjadi 408.233 rumah tangga atau mengalami penurunan sebesar 84.161 rumah tangga. Hal ini akan menjadi 


\begin{abstract}
permasalahan serius dalam mempertahankan sistem subak yang menjadi warisan dunia karena tanpa adanya regenerasi petani secara sendirinya sistem subak akan mati. Regenerasi petani sudah saatnya menjadi perhatian serius, masalah regenerasi petani ini memang terlihat biasa-biasa saja saat ini,tidak terlihat penting,tidak berdampak drastis,tetapi suatu saat akan membawa efek yang berbahaya di masyarakat khususnya bagi keberlangsungan Subakdi Bali.

$\begin{array}{rrr}\text { Keberadaan } & \text { subak } & \text { sebagai } \\ \text { Warisan Budaya } & \text { Dunia } & \text { (WBD) }\end{array}$
nampaknya belum menjadi daya tarik kalangan muda untuk terjun ke dunia pertanian sehingga perlu dicarikan solusi untuk petani Bali tetap ada sehingga keberadaan subak juga tetap ada. Berdasarkan uraian diatas, pokok permasalahan yang dapat dikemukakan adalah "Apakah permasalahan regenerasi petani Bali dalam mempertahankan Subak sebagai Warisan Budaya Dunia?"
\end{abstract}

\section{PEMBAHASAN}

\section{Perkembangan Kelembagaan Subak}

Definisi subak menurut berbagai sumber antara lain, Leafrink dalam Windia (2015) menyatakan bahwa subak adalah lembaga yang mengatur air ke sawah-sawah untuk pertanian. Selanjutnya Grader menyebutkan bahwa subak selain sistem irigasi yang baik, juga sangat efektif digunakan untuk memungut pajak tanah (land rent). Sementara itu, Raka (1955) mengatakan bahwa subak adalah perkumpulan sawah yang mendapatkan air dari satu aliran sungai, atau salah satu cabang/anak sungai.

Menurut Pitana (1993), subak merupakan organisasi petani lahan basah yang mendapatkan air irigasi dari suatu sumber bersama, memiliki satu atau lebih Pura Bedugul, serta memiliki kebebasan dalam mengatur rumah tangganya sendiri maupun dalam berhubungan dengan pihak luar. Definisi ini mengandung aspek fisik dan sosial. Aspek fisik subak adalah hamparan persawahan dengan segenap fasilitas irigasinya, sedangkan aspek sosial subak adalah organisasi petani irigasi yang otonom.

Subak adalah suatu masyarakat hukum adat yang memiliki karakteristik sosio-agraris-religius, yang merupakan perkumpulan petani yang mengelola air irigasi di lahan sawah. Pengertian subak seperti itu pada dasarnya dinyataan dalam peraturan daerah pemerintah daerah Provinsi Bali No.02 / PD/DPRD/1972. Pada perkembanganya ada beberapa tokoh yang memperluas pengertian karakteristik sosio-agrarisreligius dalam sistem irigasi subak, dengan menyatakan lebih tepat subak itu disebut berkarakteristik sosio-teknisreligius, karena pengertian teknis cakupannya menjadi lebih luas, termasuk diantaranya teknis pertanian, dan teknis irigasi.

Subak sebagai suatu sistem irigasi merupakan teknologi sepadan yang telah menyatu dengan sosiokultural masyarakat setempat. Kesepadan teknologi system subak ditunjukkan oleh anggota subak tersebut 
melalui pemahaman terhadap cara pemanfaatan air irigasi yang berlandaskan Tri Hita Karana (THK) yang menyatu dengan cara membuat bangunan dan jaringan fisik irigasi, cara mengoperasikan, koordinasi pelaksanaan operasi dan pemeliharaan yang dilakukan oleh pekaseh (ketua subak), bentuk kelembagaan, dan informasi untuk pengelolaannya.

Sistem subak mampu melakukan pengelolaan irigasi dengan dasar-dasar harmoni dan kebersamaan sesuai dengan prinsip konsep Tri Hita Karana (THK), dan dengan dasar itu sistem subak mampu mengantisipasi kemungkinan kekurangan air (khususnya pada musim kemarau), dengan mengelola pelaksanaan pola tanam sesuai dengan peluang keberhasilannya. Selanjutnya, sistem subak sebagai teknologi sepadan, pada dasarnya memiliki peluang untuk ditransformasi, sejauh nilai-nilai kesepadanan teknologinya dipenuhi.

Revolusi hijau telah menyebabkan perubahan pada sistem irigasi ini, dengan adanya varietas padi yang baru dan metode yang baru, para petani harus menanam padi sesering mungkin, dengan mengabaikan kebutuhan petani lainnya. Ini sangatlah berbeda dengan sistem Subak, di mana kebutuhan seluruh petani lebih diutamakan. Metode yang baru pada revolusi hijau menghasilkan pada awalnya hasil yang melimpah, tetapi kemudian diikuti dengan kendalakendala seperti kekurangan air, hama dan polusi akibat pestisida baik di tanah maupun di air. Akhirnya ditemukan bahwa sistem pengairan sawah secara tradisional sangatlah efektif untuk menanggulangi kendala ini.

\section{Permasalahan Regenerasi Petani}

Regenerasi petani sudah menjadi keharusan mendapatkan perhatian serius karena dalam 10 tahun terakhir jumlah petani terus menurun. Berdasarkan data sensus pertanian tahun 2013 di Provinsi Bali dalam kurun waktu 2003-2013 terjadi penurunan jumlah rumah tangga petani sebesar $17,09 \%$. Penurunan ini terjadi sebagian besar karena berpindah kerja ke sektor lain dan sedikitnya tenaga kerja baru yang menajadi petani.

Penurunan minat generasi muda di bidang pertanian juga disebabkan karena aspek sosial dan ekonomi yang kurang mendukung. Kondisi lingkungan sosial di masyarakat masih menganggap bahwa petani adalah pekerjaan yang kotor,petani merupakan golongan orang yang miskin dan lain sebagainya. Selain itu generasi muda menganggap sektor lain lebih menjanjikan secara ekonomi sehingga sektor pertanian dipandang sebelah mata.

Ketidaktertarikan anak muda akan pertanian setidaknya disebabkan oleh tiga hal (White, 2012).

1) Sistem pendidikan yang menanamkan ide bahwa bertani bukan sebagai usaha atau pekerjaan yang menarik. Di bangku sekolah, umumnya pertanian tidak digambarkan sebagai sektor strategis yang turut menggerakkan ekonomi nasional.

2) Adanya pengabaian dalam jangka panjang oleh pemerintah terhadap 


\section{Dwipradnyana : Tantangan Petani Bali dalam Mempertahankan Subak}

pertanian skala kecil yang merupakan penyerap kerja yang sangat besar serta terhadap pembangunan pedesaan di banyak wilayah. Hal ini pada gilirannya mengakibatkan kegiatan bertani menjadi kurang menjanjikan secara ekonomi.

3) Keterbatasan akses generasi muda terhadap lahan yang disebabkan oleh pencaplokan lahan dan konsentrasi kepemilikan lahan. Di tingkat keluarga, akses lahan melalui warisan harus menunggu waktu lama atau setelah orang tua meninggal. Saat orang tua masih hidup, mereka tidak mau menghibahkan lahan pada anaknya karena kekuatiran akan kemampuan anak dalam mengelola lahan atau ketakutan bahwa lahan tersebut akan dijual.

\section{Tantangan Berat Regenerasi Petani Bali}

Regenerasi merupakan tantangan yang dihadapi oleh sektor pertanian di Bali dalam usaha untuk melestarikan Subak sebagai Warisan Budaya Dunia (WBD). Tantangantantangan tersebut akan diuraikan dibawah ini yaitu sebagai berikut.

1) Sektor pertanian kalah bersaing dengan sektor pariwisata

Bali yang merupakan daerah tujuan wisata secara tidak langsung memiliki andil yang sangat besar dalam proses kegagalan regenerasi petani di Bali. Pemikiran generasigenerasi muda Bali semua terpusat pada pariwisata dengan melihat kemewahan hotel-hotel berbintang yang sangat jauh bila dengan pertanian yang bekerja di lumpur. Maka tidak heran ada anggapan dari kalangan akademisi pertanian bahwa pariwisata mematikan pertanian. Secara perlahan sektor pertanian akan tergerus bukan hanya lahan yang digunakan sebagai sarana pariwisata namun generasi-generasi penerus petani juga di"curi" sehingga sektor pertanian hanya digeluti oleh orang-orang tua yang memiliki produktifitas yang rendah.

2) Risiko gagal yang dihadapi menjadi petani sangat besar

Generasi-generasi muda Bali enggan terjun ke dunia pertanian karena melihat risiko gagal yang sangat besar dalam bertani. Menjadi petani adalah pekerjaan yang sulit karena akan berhadapan dengan alam yang tidak dapat dikendalikan oleh manusia. Melihat hal terebut anak-anak muda akan lebih tertarik bekerja di sektor lain yang tidak memiliki risiko tinggi walaupun dengan penghasilan di bawah standar.

3) Generasi muda menganggap sektor lain lebih menjanjikan secara ekonomi

Hasil pertanian walaupun dibutuhkan oleh semua lapisan masyarakat namun dalam hal pendapatan sektor pertanian masil kalah dengan sektor-sektor lain, sehingga sektor pertanian menjadi pilihan terakhir bagi generasigenerasi muda Bali. Secara ekonomi sektor pertanian jika 
dilihat dari hitung-hitungan diatas kertas tentu sangat menguntungkan namun di lapangan terdapat banyak permasalahan seperti harga bibit dan pupuk tinggi, serta permainan harga pasca panen dari para pengepul sehingga petani akan dirugikan.

4) Pemerintah lebih memihak pada faktor yang dianggap lebih cepat memacu pertumbuhan ekonomi

Tidak dapat dipungkiri bahwa Pemerintah khususnya Pemda Provinsi Bali kurang maksimal dalam pengembangan pertanian di Bali. Pemerintah lebih fokus pada sektor pariwisata yang memang lebih cepat memacu pertumbuhan ekonomi. Jika pemerintah semakin mengganggap sebelah mata pertanian di Bali maka pertanian Bali hanya menghitung hari dan Subak sebagai Warisan Budaya Dunia (WBD) juga akan menghilang.

\section{Solusi Regenerasi Petani Bali}

Jika dilihat dari kenyataan yang ada saat ini, melihat kondisi pertanian yang semakin terjepit dan sangat sedikitnya generasi-generasi muda Bali yang terjun ke pertanian maka harus dicarikan solusi agar pertanian Bali dan Subak yang ada di dalamnya dapat tetap berkelanjutan. Adapun solusi yang dapat ditawarkan adalah sebagai berikut.

1) Untuk menghadapi persaingan dengan sektor lain khususnya sektor pariwisata adalah dengan mengembangkan pariwisata berbasis pertanian. Sektor pariwisata dengan sektor pertanian adalah dua sektor yang saling membutuhkan sehingga dibutuhkan kerjasama yang baik antar kedua sektor ini sehingga pariwisata tidak mematikan petani. Solusi yang dapat ditawarkan adalah pemerintah dapat mengeluarkan himbauan kepada pengusaha-pengusaha di sektor pariwisata untuk dapat menggunakan hasil pertanian lokal sehingga hasil pertanian di Bali memiliki pasar yang jelas.

2) Untuk meminimalisir risiko yang dihadapi petani perlunya peran yang lebih dari penyuluh-penyuluh pertanian maupun akademisiakademisi di bidang pertanian untuk memberikan ilmu kepada petani-petani untuk menghadapi permasalahan yang mereka hadapi sehingga risiko gagal panen dapat diminimalisir.

3) Menghilangkan anggapan bahwa sektor pertanian adalah untuk rakyat miskin dan tidak menjanjikan dari segi ekonomi. Sektor pertanian merupakan peluang usaha yang sangat menjanjikan jika dapat dikelola dengan baik. Solusi yang dapat diberikan adalah dengan memperbanyak pelatihan-pelatihan dan pengembangan-pengembangan teknologi di bidang pertanian sehingga generasi muda dapat tertarik terjun ke bidang pertanian.

4) Pemerintah sebaiknya lebih memperhatikan sektor pertanian dengan memberikan subsidi-subsidi 


\section{Dwipradnyana : Tantangan Petani Bali dalam Mempertahankan Subak}

maupun kebijakan-kebijakan yang mendukung petani seperti pembebasan pajak bumi dan bangunan kepada petani sehingga penghasilan petani dapat lebih tinggi dengan harapan sektor pertanian lebih digemari oleh generasi-generasi muda. Selain itu dalam mengembangkan pertanian pemerintah sebaiknya membuat terminal-terminal agribisnis untuk mempermudah petani memasarkan hasil pertaniannya sehingga tidak dipermainkan oleh pengepulpengepul dan ada kepastian bagi petani dimana menjual dan adanya kepastian harga.

\section{SIMPULAN DAN SARAN}

\section{Simpulan}

Mempertahankan Subak sebagai Warisan Budaya Dunia (WBD) memiliki tantangan yang sangat berat terutama dalam regenerasi petani. Tantangan yang dihadapi dalam regenerasi petani adalah sektor pertanian kalah bersaing dengan sektor pariwisata, risiko gagal yang tinggi dalam pertanian, generasi muda menganggap sektor lain lebih menjanjikan secara ekonomi dan pemerintah lebih memihak pada faktor yang dianggap lebih cepat memacu pertumbuhan ekonomi.

\section{Saran}

$$
\begin{aligned}
& \text { Menyadari akan adanya } \\
& \text { permasalahan yang dihadapai dalam } \\
& \text { regenerasi petani maka saran yang dapat }
\end{aligned}
$$

diberikan adalah peran serta pemerintah harus lebih ditingkatkan dengan cara memadukan pariwisata dengan pertanian sehingga terjadi hubungan yang saling menguntungkan, memperbanyak pelatihan-pelatihan dan pengembangan teknologi serta menyediakan terminal-terminal agribisnis untuk mempermudah petani memasarkan hasil pertaniannya ada kepastian bagi petani dimana menjual dan adanya kepastian harga.

\section{DAFTAR PUSTAKA}

Ambler, John S., 1991. "Perkumpulan Petani Pemakai Air di Indonesia: Tradisi dan Masa Depan”, dalam Effendi Pasandaran (ed). Irigasi di Indonesia: Strategi dan Pengembangan. Jakarta: LP3ES., 297-312.

Badan Pusat Statistik (BPS). Sensus Pertanian Tahun 2013, Bali, 2017

Badan Pusat Statistik (BPS). Bali Dalam Angka 2016, Bali, 2016

Devi, MKS. 2015. A study on the influencing factors for a literate youth to take up agricultural entrepreneurship. International Journal of Management and Commerce Innovations 3 (1): 692-700

Pitana, I.G. 1993. Performance indicators: A case of a newly developed FMIS in Bali, Indonesia. In Performance measurement in farmermanaged irrugation system. Proceedings of an international 
workshop of the farmer-

managed irrigation system network, ed. S. Manor and J.

Chambouleyron,

$13-$.

Colombo, Sri Langka:

International Irrigation

Management Institute.

Sutawan, N., M. Swara, W. Windia, W. Suteja, W. Sudana dan K. Suamba, 1995. Penerimaan dan Pengeluaran Organisasi Subak dan Subak-gede di Lingkungan Subak-agung Yeh Ho, Kabupaten Tabanan dan Subak-agung Gangga Luhur,Kabupaten Buleleng, Propinsi Bali. Denpasar: Universitas Udayana. Mimeo.

White, B. 2012. Agriculture and The Generation Problem: Rural Youth, Employment and the Future of Farming. IDS Bulletin, 43 (6), pp. 9-19.

Windia, Wayan. 2006. Transformasi Sistem Irigasi Subak yang Berlandaskan Konsep Tri Hita Karana. Pustaka Bali Post, Denpasar

Windia, Wayan.dkk. 2015. Sistem

Subak di Bali (Kajian Sosiologis). Udayana University Press, Denpasar

Windia,W dan W.A.A.Wiguna. 2013.Subak Warisan Budaya Dunia.Udayana University Press, Denpasa 
